\title{
A Variationist Approach to Nigerian English Phonology
}

\author{
Olaniyi Oladimeji ${ }^{1, *}$ \\ ${ }^{1}$ Department of English and Literary Studies, Federal University, Lokoja Nigeria \\ *Correspondence: Department of English and Literary Studies, Federal University, Lokoja, Nigeria. Tel: \\ 234-806-649-7280 E-mail: Dejiolaniyi80@Gmail.com
}

Received: June 22, 2016

Accepted: July 21, 2016 Online Published: September 24, 2016

doi:10.5430/wjel.v6n3p42

URL: http://dx.doi.org/10.5430/wjel.v6n3p42

\begin{abstract}
Since the Phonology of Nigerian English has been described variously by different researchers this paper sought to explained the features of Nigerian English from the perspectives of the sociolinguistic variables of age, sex, occupation, education, exposure and motivation. The study examined the factors that underscore the social and ethnic variables exhibited by Educated Nigerians in their attempt to use the English language efficiently at the phonological level. The theoretical framework for this study wasthe adapted synthesis of ascribed and acquired sociolinguistic variables according toLabov (1966) and Preston (1989). The data for the study were elicited from over a hundred speakers of English selected along the lines of the different variables earlier mentioned. Their voices were recorded and their renditions were phonemically transcribed in the A.C. Gimson's model of transcription and acoustically analyzed using the Pratt software. The findings in the study suggest among others that adult speakers of English in Nigeria perform better in approximation to Standard British English. It also reveals that the vocalic system in Hausa, Yoruba and Igbo languages shares slightly,lengthening of English vowel quality as demonstrated by our subjects.Some Nigerian Female speakers of English tend to devoice voiced consonants in their speeches. On the whole, we concluded that all the sociolinguistic variables best explain the differences and the features in the quality of speech sounds observed among Nigerian speakers of English.
\end{abstract}

Keywords: phonology; variability rule; sociolinguistics; nigerian english; variables

\section{Introduction}

To many scholars, language is one of the most salient dimensions in group identification. Sachdevand Bourhis (1990:216-217) suggest that language acts both as a marker and maker of social identities (Kristiansen 2003:105). The implication of the 'markings' and 'making' of social identities has been that non-native English varieties across the world have gained their own recognition and might be gaining a pride of place in the company of World Englishes.

To make the direction of this paper, four matters are being brought to the fore as a corroborative attempt for all the research efforts in the area of Nigeria English Phonology. The various findings of Banjo (1971), Akinjobi (2002), Josiah (2009) and Olaniyi (2011) among others are evidences of a prototype Nigerian English which we shall review in the subsequent sections in this paper. However, the purpose of this paper is to disambiguate issues such as identity markers, variable rule, and cognitive phonology and to make a case for the autonomy of Nigerian English.

Nigerians, over one hundred and sixty million in population have affiliations to different groups. These groups make Nigeria a greatly multicultural or multilingual society. The constitution of Nigeria recognizes three major languagesHausa, Igbo, and Yoruba, among the about 400 speech forms of the federation, each of them representative of a major region: North, East and West (see Adegbija 2004) and at present six- geo- political zones: North east, North West, North Central, South West, South East and South-South. All the major and minor groups fall within these regions. These divisions explain why ethnicity is a major divide in Nigeria. Scholars such as Jubril (1982), Eka (1985), Olaniyi (2011) have accorded ethnicity a prominent place in the identification of Nigerians especially when they communicate in the further tongue. As Bamgbose(1971:24) reports, many Nigerians are able to identify a speaker's ethnic group as soon as he speaks a few words of English. Olaniyi(2011) sees ethnic interference phenomenon in the light of bilingualism and its attendant level of linguistic analysis. 
Secondly, variability rule or 'Varbrul" based on Preston's (1989) postulation is relevant in phonology and sociolinguistics, since any variation in syntax and semantics in second language contexts is considered a demonstration of incompetence. There is bound to be variations in any living language, since "no two speakers of a language, even if they are speakers of the same dialect, produce and use their language in exactly the same way all the time. (cf. Akmajian 2001:277).

For many linguists, the psycholinguistic status of a linguistic fact is best expressed in a rule (Preston1989:13). The concern of sociolinguists with language variation culminated in the formation of rules, such as the VARBRUL. Some of the rules are categorical and work everywhere, i.e., they are applicable on any natural language (Preston 1989:13). Unlike other sociolinguistics theories such as the interlanguage theory, and the deficit hypothesis which are normative in their approach to sociolinguistics research, the procedure employed by the variability concept is descriptive. It is not only descriptive but also not given to prejudice. The concept does not recognize the superiority of any language or speech form over another. The VARBRUL is strong because it is not one sided as it recognizes the functional equivalence of language and relates with the different socio-situations. The socio-cultural variables which VARBRUL propagates include gender, literary, age and origin among these variables will form the nexus of our discussions I this paper. Cognitive phonology on its part is a branch of cognitive linguistics a recent focus of researchers all over the world. According to Kristiansen (2003:71) there exists a relationship between accents and society, despite its problems.

Apart from contributing substantially to the interpretation of sociolinguistics data, the field can also benefit from an application of its framework to such a rich complex and well- documented field. In a study by Kristiansen (2003:69-120), he posits that 'doing things with allophones' can be a reference point in social cognitive linguistic stereotyping process. A cue from this study justifies our cognitive approach to phonological analysis in English as a second language context.

The last matter of interest in this paper is the seemingly controversial argument on the status of Nigerians English among the varieties of English across the world. Elsewhere Olajide and Olaniyi (2013) have attempted to defend a course in favour of Educated Nigerian English as a 'core' of a standard variety of spoken English. In the light of that position, our purposes in this paper is to argue in support of a position that a reconciliation of all the features prescribed by the variability rule should provide a ground for the already established Nigeria English variety to thrive as an autonomous strand of non-native spoken variety of English which is internationally intelligible.

\section{Literature Review of Nigerian English}

Relatively appreciable volumes of literature of Nigerian English from the sociolinguistic angle now exist although most of the studies on speech behavior of Nigerians have been purely phonological. The question therefore, of whether there is a form of English that could be regarded as Educated or Basic Nigerian English (Jibril 1982, Eka 1985) has become irrelevant in 2015. This is because dominant in the literatures of second language English is the recognition of the evolution of a form of English that is obviously different from Standard English and peculiarly Nigerian (see Banjo 1971a).

Making a reference to Adetugbo $(1979,1980)$, Ogu (1992) notes that diachronically, a variety of English (yet to be fully described) has been identified as Nigerian. Kachru (1995) also notes in his foreword to the bookNew Englishesthat the African cannon of the English language (of which Nigerian English is a variety) has been established and recognized and that it is indeed a vital component of the World Englishes.

Obviously, there are features at every level of Language that could be marked distinctively as Nigerian (see Ufomata 1990, Jowitt, 1991, Egbe 1992). Rather than belabour ourselves with the question of whether Nigerian English exists or not, Bamgbose, in an article published in the national concord of eleventh of July, 1986 proposed that the concentration should be on the interesting task of specifying, describing and analyzing the forms of the variety (cf. Jibril, 1982). After this publication, a lot has been done on the task of describing the Nigerian English in relation to phonology, syntax, lexis and semantics. Notable scholars in these different fields have come out with different data to support their claims that there exists a variety of English that is Nigerian (see Kujore 1985, Ufomata 1990, Jowitt 1991, Banjo 1995). Jowitt (1991) claims that there is such an abundance of data that a sizeable team can collect and catalogue. In fact, up till now, efforts are still being made toward codifying Nigerian English (NE) in all its aspects. The latest effort is the publication of a dictionary of Nigerian English by the Nigeria English Studies Association team in 2014

This present research work is aimed at contributing to the research efforts of researchers who seek to describe NE 
and identify those who speak the non-native variety of English. This present study is delimited and stratified according to the variables of age, level of education, sex, ethnicity and socio-historical background (see Preston 1989:53-109). Nigerians who have acquired at least the Higher National Diploma (HND), certificate with years of corporate working experience are randomly chosen.

To identify NE by the variables in Preston (1989), revisiting the codified forms of NE is thus imperative. Kachru (1982) identifies "four arms of codification" (i.e. agents of standardization) as authoritative (e.g. the academies set up for some languages in Europe); sociological, attitudinal, psychological and education (e.g. through the use of instruments such as the dictionary, the mass media etc.). Banjo (1995) on the other hand views social acceptability and international intelligibility as essential criteria for identifying a standard. He however, explains that though social acceptability is clearly subject to the democratic process and international intelligibility more elite inclined, the standard will have to be located between the products of the two criteria.

Until recently, it was noted at the Nigeria English Studies Association (NESA) conference held in 2009 at the Tai Solarin University of Education, Ijebu-Ode, that there have been wasteful efforts towards the codification of Nigerian English due to incessant emphasis on the issue over the years by researchers. The president of the association at the Annual General Meeting (AGM 2009) emphasised the need for papers that will lead to the realization of the dream to codify Nigerian English. Earlier, Kujore (1990:25) notes that "the establishment of the standard variety of Nigerian English has remained a myth because of the lack of codification of these variations". Banjo in his foreword to Kujore's (1985) English usage: some notable Nigerian variations craves for a purely descriptive study in terms of how the language is spoken rather than who, why and when - these being sociolinguistic concern (see Jowitt 1991). According to Kujore (1985:32) there is "the need to describe these variations scientifically for the effective codification of its grammar and form so as to have a common point of reference to which learners and users may turn for normative guidance. Furtherance to that goal, this present study seeks to make a case for the autonomy of Nigerian English drawing inferences from the sociolinguistics variables whose network is the framework for the analysis of our data in this study.

\section{Theoretical Framework}

The following schema captures the requirements of sociolinguistics and linguistic behavior.

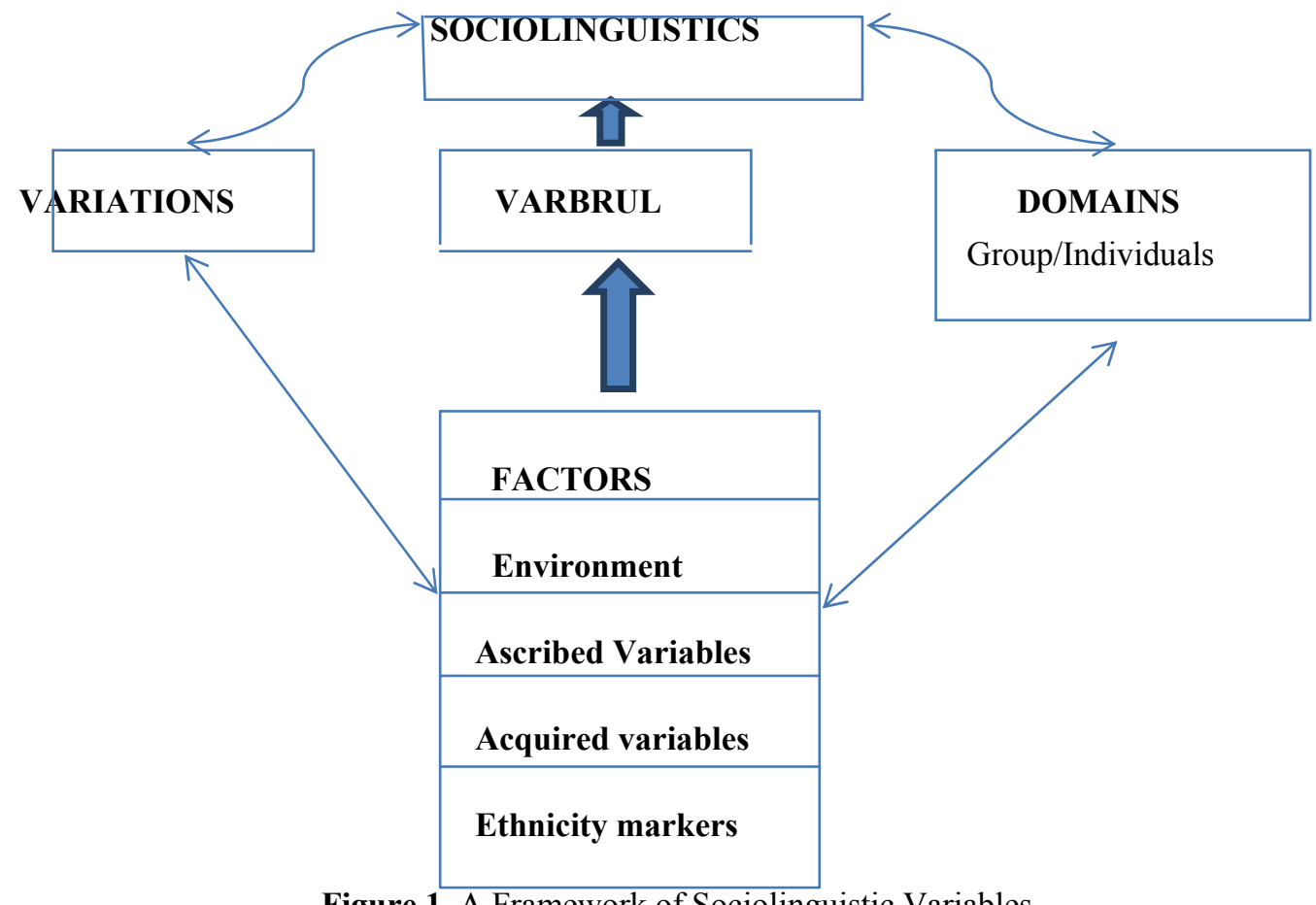

Figure 1. A Framework of Sociolinguistic Variables 
The major sociolinguistic variables, as factored in the figure above and elaborated in Preston (1989) have been adopted for our data analyses. The network has the variationist ideology as the meeting point. The central idea of the variations, variables and the domains derive from the factors that cause individuals to speak the English language the way they do. First is the environment of the learner of a first or second language. The linguistic and social environment of a learner may influence his use of the language and variables are ascribed sociolinguistically to speakers of a language. The ascribed variables include age, sex, nativity, ethnicity and region. Unlike the ascribed variables, some variables are acquired. The acquired variables include roles, specialization, status, fluency and above all individuality. The model also recognizes some social and historical variables such as Topos (territory), Genesis (origin) Onyma (identity), Polis (organization), Ethos, (values / beliefs) Nomos (customs), Glossa (language), and Techne (material culture) etc., according to Brann (2006). How these variables influence non-native spoken English is $\mathrm{x}$-rayed in the analyses below.

\section{Methodology}

Five stages were involved before the analysis of our data in this study was carried out. The recorded voices of 100 Nigerians who belong to different professions and disciplines were transcribed orthographically and phonemically. The various professionals were grouped according to their level of education. Thus, the methodology employed in this study took the following turns: Data were selected according to the variables of education and time of exposure to the English Language among other variables in Preston (1989:53-109); the procedure of analysis involved perceptual and acoustic analysis. In an instance of complementing the perceptual analysis, the research population and sampling of 100 respondents was done. The subjects were carefully selected to represent the ethnic, geographical, gender and occupational divides in Nigeria. The variability rule proposed by Labov (1966) and elaborated in Preston (1989) forms the framework for the analysis of our data in this study.

\section{Data Presentation and Analyses}

The sampled voices recorded for this study is analyzed thus: Standard English phonemes sometimes share different realizations in different environments. The different realizations of these phonemes as observed by our subjects are what we want to present in this section before we discuss the other variables. The sentence - "moreover common wealth is an example of multilateralism at work", a sentence in our corpus was read by 21 participants. In the sample, our subjects from the three major ethnic groups in Nigeria were tested on the following phonemic variables in the different linguistic environments that we have presented below. Variables /ə/ and /3: / are regarded as the schwa and the mid central long vowel. The schwa featured in the peak of the last syllable of the word 'moreover". The long mid central vowel featured in the peak of the monosyllabic word, 'work'. Our subjects rendered the phonemes as shown below:

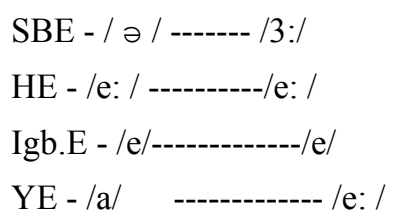

In the renditions the schwa and the long mid central vowel number eleven were rendered differently by our subjects. In the British version,there is a change of vowel from / / / to /3:/ while in the Hausa version, there is the lengthening of a monophthong /e/ to /e:/. For the Igbo speaker, there is the maintenance of a monophthong /e/ as /e/and a changing of /a/ lower variety of /æ/ to /e:/ by the Yoruba speaker.

The short schwa is centralized, mid, short lax R.P vowel with neutral lips position in articulation. The difference between the short schwa andvowel number eleven is the length. It poses the greatest difficulty to Nigerians to pronounce. Only 6 of our 21 broadcasters could pronounce the schwa sound almost correctly. The remaining 15 were capable of pronouncing what appears to be the equivalence of the schwa sounds in their dialects.

In the word lists provided as well there were distinctions in the phonemic realizations of our control and experimental subjects. In the pronunciation of the phoneme $/ \Lambda /$ words such as thorough, honour, cut featured. We observed that not even the broadcasters could produce the exact quality of the vowel. We then sought acoustic means to see the differences in timing between SBE Jand ENE. $/ \mathrm{\Lambda} /$, the central, short, open, low RP phoneme is generally pronounced $/ \mathrm{J} /$ by ENE speakers. We found few correct production of $/ \Lambda /$ among the Hausa speakers of English. This will be further elaborated in the course of these analyses. 
Variables $/ \Theta /, / \mathrm{d} /, / \mathrm{j} /, / \curvearrowright /, / 3: /, / \Lambda /, / \mathrm{f} /$ and $/ \mathrm{v} /$ were among the vowels and consonants that were tested. We noticed the following alternatives being provided by our subjects. $/ \mathrm{t} /$ is rendered as $/ \mathrm{\theta} /, / \mathrm{d} /$ is rendered as $/ \mathrm{d} /, / \mathrm{j} /$ by a reasonable number of subjects is rendered as $/ \mathrm{j} /, / \mathrm{p} / \mathrm{as} / \mathrm{fp} /, / \mathrm{N} /$ as $/ \mathrm{J} / \mathrm{and} / \curvearrowright, 3: /$ as $/ \mathrm{a}, \mathrm{J}, \varepsilon /$ as the case may be. Inconsistencies among the subjects were very prevalent among the Hausa speakers. We have carefully presented in the table below, 'an implicational ordering of articulations of $/ \mathrm{e} /, / \mathrm{d} /, / \mathrm{j} /, / \mathrm{L} /, / \curvearrowright /, / 3: /$ and $/ \mathrm{f} /$.

Table 1. Articulation of Phonemes in Different Linguistic Environments

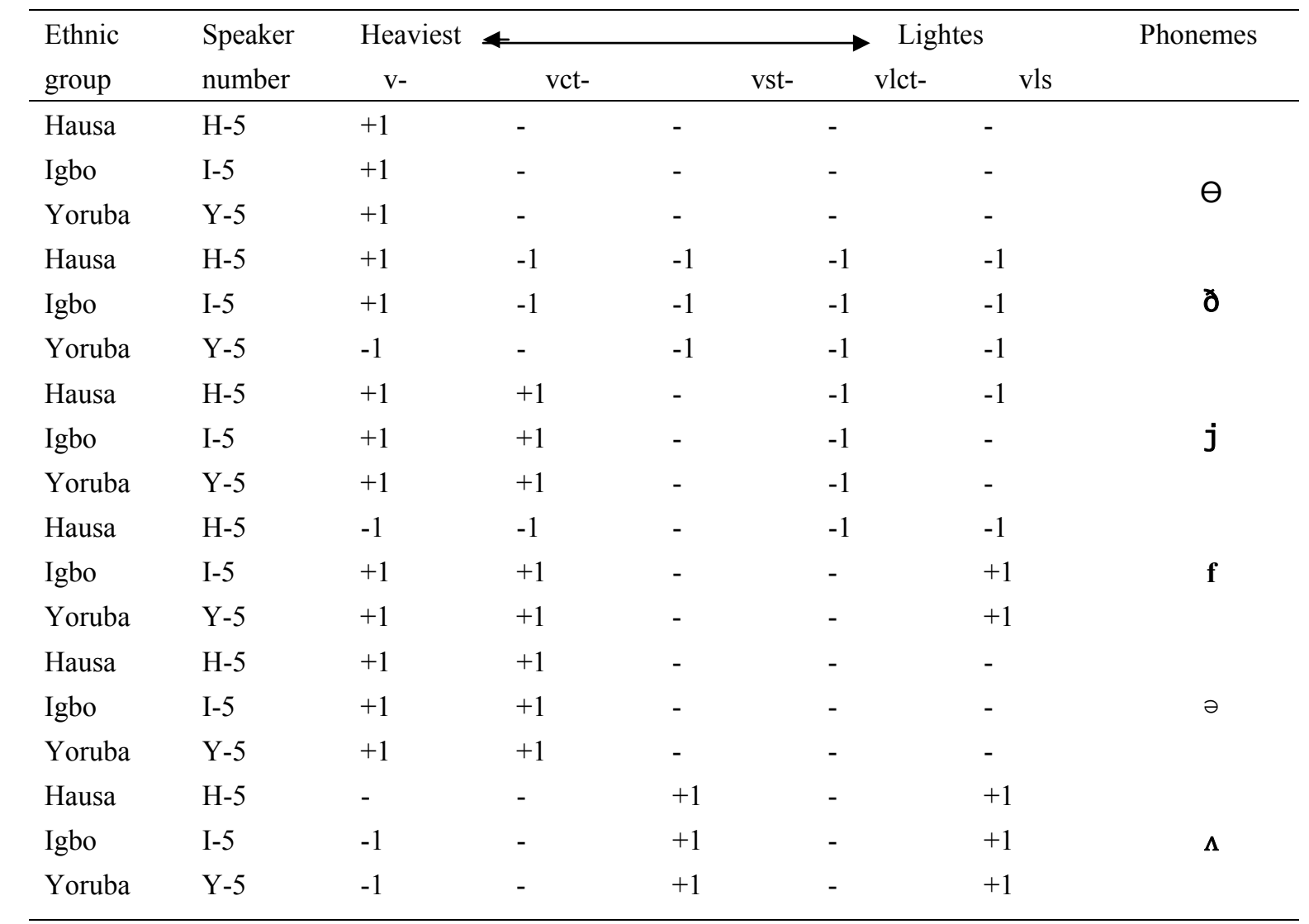

Key

+1 --- Presence of native-like articulation

-1 --- Presence of non-native like articulation

- $\quad$--- not applicable

$\mathrm{v}$--- Preceding vowel

vct --- Preceding voiced continuant

vst ---Preceding voiced stop

Vlct --- Preceding voiceless continuant

Vls ---Preceding voiceless stop

In a nutshell, the table reveals that Nigerian speakers of English have comparative advantage in the articulation of consonant phonemes preceding vowels than where there are clusters of consonants, or where the sample consonants above appear before voiceless stops or continuants as shown in the table above by our subjects in words such as 'oath', 'wriothesley'/raIəөsII/, 'wyvern' /waIvən/, 'wythenshawe', /wIðənfJ: /, 'wroth', /rəve/, würzburg., /v3:ts.buəg/, 'wrong foot', /rnjfut/, cup, cub, etc. In the table above some feature appear not applicable. So, we have ignored such examples.

The Linguistic environment alone appears inadequate for the explanation of the reason why there are different or alternative phonemic realizations as shown above. Social variables have been recognized to give some reliable 
description of a speaker's L1 and L2 phonological competence. Sociolinguistically, speaking, the Hausa speakers of English in our corpus have proved that they are natural bilinguals who individually speak their local dialects as well as a standard Kananci, from our investigation. A probe into the ethnic backgrounds of our Yoruba speakers of English reveal that they speak one of the Yoruba dialects- Egba, Ekiti, Igbomina, Ijebu, Ondo and the court of Oyo dialect. The level of bilingualism of our subjects varies with the frequency of interaction, level of formal education, age and linguistic aptitude of our subjects. Taking a cue from Adegbite's (2009) classification.

Table 2. Social Stratification of ENE Subjects

\begin{tabular}{|c|c|c|c|c|c|c|c|}
\hline A & B & $\mathrm{C}$ & $\mathrm{D}$ & $\mathrm{E}$ & $\mathrm{F}$ & G & $\mathrm{H}$ \\
\hline Subjects & Number & Occupation & Ethnicity & Age & $\begin{array}{l}\text { Minimum } \\
\text { education }\end{array}$ & $\begin{array}{l}\text { Performance } \\
\text { rating }\end{array}$ & $\begin{array}{l}\text { Subjective } \\
\text { competence } \\
\text { rating/remark }\end{array}$ \\
\hline A-21 & $\begin{array}{l}1-7 \\
8-15 \\
16-21\end{array}$ & Students & $\begin{array}{l}\text { Hausa } \\
\text { Igbo } \\
\text { Yoruba }\end{array}$ & $19-23$ & Undergraduate & $\begin{array}{l}\text { Nigerian } \\
\text { accent } \\
100 \%\end{array}$ & $\begin{array}{l}\text { Not } \\
\text { aspirarable }\end{array}$ \\
\hline B-21 & $\begin{array}{l}22-28 \\
29-35 \\
36-42\end{array}$ & $\begin{array}{l}\text { Post } \\
\text { graduate } \\
\text { students }\end{array}$ & $\begin{array}{l}\text { Hausa } \\
\text { Igbo } \\
\text { Yoruba }\end{array}$ & $27-45$ & $\begin{array}{l}\text { Post graduate } \\
\text { student }\end{array}$ & $\begin{array}{l}\text { Educated } \\
\text { Nigerian } \\
\text { accent } 90 \%\end{array}$ & Not aspirable \\
\hline C-15 & $\begin{array}{l}43-47 \\
48-52 \\
53-57\end{array}$ & Lecturers & $\begin{array}{l}\text { Hausa } \\
\text { Igbo } \\
\text { Yoruba }\end{array}$ & $29-60$ & $\begin{array}{l}\text { First degree to } \\
\text { Professorship }\end{array}$ & $\begin{array}{l}\text { Educated } \\
\text { Nigerian } \\
\text { accent } 60 \%\end{array}$ & $\begin{array}{l}\text { aspirable } \\
\text { with } \\
\text { reservations }\end{array}$ \\
\hline D-15 & $\begin{array}{l}58-62 \\
63-67 \\
68-72\end{array}$ & Doctors & $\begin{array}{l}\text { Hausa } \\
\text { Igbo } \\
\text { Yoruba }\end{array}$ & $29-45$ & $\begin{array}{l}\text { First degree to } \\
\text { professorship }\end{array}$ & $\begin{array}{l}\text { Educated } \\
\text { Nigerian } \\
\text { accent } 60 \%\end{array}$ & Aspirable \\
\hline E-15 & $\begin{array}{l}73-77 \\
78-82 \\
83-87\end{array}$ & Lawyers & $\begin{array}{l}\text { Hausa } \\
\text { Igbo } \\
\text { Yoruba }\end{array}$ & $29-50$ & First degree & $\begin{array}{l}\text { Educated } \\
\text { Nigerian } \\
\text { accent } 50 \%\end{array}$ & Not aspirable \\
\hline F-12 & $\begin{array}{l}88-91 \\
92-95 \\
96-99\end{array}$ & Architects & $\begin{array}{l}\text { Hausa } \\
\text { Igbo } \\
\text { Yoruba }\end{array}$ & $28-50$ & First degree & $\begin{array}{l}\text { Educated } \\
\text { Nigerian } \\
\text { accent } \\
60 \%\end{array}$ & $\begin{array}{l}\text { Aspirable } \\
\text { with } \\
\text { reservations }\end{array}$ \\
\hline G-12 & $\begin{array}{l}100-103 \\
104-107 \\
108-111\end{array}$ & $\begin{array}{l}\text { Civil } \\
\text { servants }\end{array}$ & $\begin{array}{l}\text { Hausa } \\
\text { Igbo } \\
\text { Yoruba }\end{array}$ & $32-50$ & $\begin{array}{l}\text { HND and } \\
\text { above }\end{array}$ & $\begin{array}{l}\text { Nigerian } \\
\text { English } \\
85 \%\end{array}$ & Not aspirable \\
\hline H-15 & $\begin{array}{l}112-116 \\
117-121 \\
122-126\end{array}$ & Politicians & $\begin{array}{l}\text { Hausa } \\
\text { Igbo } \\
\text { Yoruba }\end{array}$ & $30-45$ & $\begin{array}{l}\text { First degree } \\
\text { and above }\end{array}$ & $\begin{array}{l}\text { Educated } \\
\text { Nigerian } \\
\text { English } \\
70 \%\end{array}$ & Not aspirable \\
\hline I-24 & $\begin{array}{l}127-134 \\
135-142 \\
143-150\end{array}$ & $\begin{array}{l}\text { Journalists } \\
\text { and } \\
\text { broadcaster }\end{array}$ & $\begin{array}{l}\text { Hausa } \\
\text { Igbo } \\
\text { Yoruba }\end{array}$ & $30-50$ & $\begin{array}{l}\text { HND and } \\
\text { above }\end{array}$ & $\begin{array}{l}\text { Towards } \\
\text { R.P } 90 \%\end{array}$ & Aspirable \\
\hline
\end{tabular}

The table above explicitly presents our subjects socially. The 150 subjects for this study are shown on the table by number from 1-150. The second column-B, are the number they have been slotted into by the researcher for easy handpick. Column $\mathrm{C}$ presents their occupational status in the society followed by their ethnic origin in column-D. In 
column-E is their age group; while in $\mathrm{F}$ is their minimum qualification. The last two columns- $\mathrm{G}$ and $\mathrm{H}$ are the subjective assessment of the 150 Nigerians, based on our perception. We shall carry out an acoustic analysis later in the study in order for us to clearly see the differences between the ENE and SBE, although our purpose in this study does not demand a matched guise.

\subsection{Ethnicity and Mother Tongue Interference}

We have accorded ethnicity a prominent place in this study by choosing 150 speakers in equal number from the three major ethnic groups in Nigeria - Hausa, Igbo and Yoruba. This accord was not merely a convenient choice but recognition of the primacy of ethnicity as the most important and most consistent co-variant of spoken English in Nigeria. As Bamgbose (1971:24) reports, many Nigerians are able to identify a speaker's ethnic group as soon as he speaks a few words of English. The most important cues which listeners use in identifying members of each ethnic group are precisely those features of language which linguists find most difficult to describe, let alone quantify. These are features of articulatory setting which determines voice quality and also rhythmic and intonation features.

The ethnic interference phenomenon is seen in the light of bilingualism and its attendant level of linguistic analysis in this study. Phonologically, our subjects could not overcome some mother tongue interference features. Some of the participants showed interferences resulting from varying mother tongues. The reason for the inability of our participants to correctly produce the / $\supset, \Lambda, 3:$, and $\mathrm{J}$ : / vowel phonemes is the varying mother tongues. The Hausa speakers of English reflected the 'shibboleths' of the Hausa language while the remaining two ethnic groups reflected their Mother tongues. We have tested the rate of interference elsewhere in this study where we mentioned the shibboleths of the three ethnic groups. Mother tongue interference does not feature as the major cognitive determinant in language acquisition.

However, the cognitive ratio of a language learner is also a key determinant of his performance in a second language. A second language learner is already exposed to his oicolect - the language of his extended family. Some learners are exposed to their Patrolect - the language of their clan. A larger group of second language learners are exposed to their ethnolect - the language of their ethnic groups. That complex linguistic variation explains why the accent of say Yoruba or Hausa differs from that of an Igbo speaker of English language. In our corpus, majority of the ENE speakers rendered some of the phonemes to reflect their immediate lects or mother tongue as presented below.

Table 3. Peculiar Nigerian English Phonemic Variables (source: author)

\begin{tabular}{|c|c|c|c|}
\hline SBE & Hausa & Igbo & Yoruba \\
\hline ə & J & J & J \\
\hline 3: & e: & e & e \\
\hline$\wedge$ & J & J & J \\
\hline $\mathrm{f}$ & $\mathrm{fp}$ & $\mathrm{F}$ & $\mathrm{f}$ \\
\hline $\mathrm{V}$ & $\mathrm{Vb}$ & $\mathrm{v}$ & $\mathrm{f}$ \\
\hline $\mathrm{p}$ & $\mathrm{Fp}$ & $\mathrm{p}$ & $\mathrm{p}$ \\
\hline t & $t$ & t & t \\
\hline $\int$ & $\int$ & $\int$ & z \\
\hline 3 & ds & 3 & ş \\
\hline $\mathrm{j}$ & $\mathrm{j}$ & $\mathrm{j}$ & $\mathrm{j}$ \\
\hline $\mathrm{h}$ & $\mathrm{h}$ & - & - \\
\hline ว: & J & J & J \\
\hline
\end{tabular}

\subsection{Age as Determinant of Variation}

We did not find out to know the ages of all our subjects but we resolved to an intelligent guess, considering the assumed age group of university undergraduates. From table 2 above, the youngest group of subjects is the students. The students interviewed in this study are twenty one in number. A perceptual study carried out on them revealed that their accent is $100 \%$ Nigerian, thereby rendering their accent, 'not aspirable'.

A careful look at table 2 shows that at the performance scale rating, 100\% rating was recorded for the undergraduate 
experimental group. The $100 \%$ rating is the highest in the table. This goes to show that the undergraduate students speak the Basic Nigerian accent.

The accent of the students is not aspirable. However, the lecturers, professionals and especially the broadcasters within age 29 to 60 are rated to speak in an accent that is locally acceptable as Educated Nigerian English and internationally intelligible as a non-native variety of Standard English in the world. The implication of this observation is that age contributes to deepness or nervousness of voice quality, which in turn determines cognitive inferiority or superiority (cf. Preston 1989:54). The voice quality of our undergraduate subjects is incomparable with that of the broadcasters and other professionals in our corpus. Unlike the undergraduates who are rated to speak Educated English in an accent described as typically Nigerian, the professionals and the broadcasters are rated above $60 \%$ in the educated variety that is close to RP in phonology and phonetics but with some ethnic peculiarities. The undergraduates produced some phonemes as presented in the table below:

Table 4. Undergraduate Subjects' Realization of Phonemes

\begin{tabular}{llcllll}
\hline Num & Word List & SBE Phonemes & H & I & Y & ENE \\
\hline 1 & Watch you & $\mathrm{t}$ & $\int$ & $\int$ & $\int$ & $\int$ \\
2 & in case & eI & e & E & e & E \\
3 & February & $\ni$ & a & a & a & a \\
4 & Ask & $\mathfrak{x}$ & a & a & a & a \\
5 & People & $\mathrm{p}^{\mathrm{h}}$ & $\mathrm{p}$ & $\mathrm{p}$ & $\mathrm{p}$ & $\mathrm{p}$ \\
6 & Physical & $\mathrm{f}$ & $\mathrm{f}^{\mathrm{b}}$ & $\mathrm{f}$ & $\mathrm{f}$ & $\mathrm{f}$ \\
7 & Health & $\mathrm{t}$ & $\mathrm{t}$ & $\mathrm{t}$ & $\mathrm{t}$ & $\mathrm{t}$ \\
\hline
\end{tabular}

Note: Hausa-H, Igbo-I, Yoruba-Y

In the table above, we perceived the variant forms of Educated Nigerian English phonemes as realized by our undergraduate experimental group. In the production of $/ \mathrm{f} /$, the voiceless affricate phoneme, the ENE version is a deviant form of $/ \int /$, what sounds like the voiceless fricative consonant phoneme in Standard English. In the production of the diphthong /eI/, the ENE versions of the sound are what sound like /eI/ in English, 'play' and what sounds like /ę/ in Yoruba 'ęge', 'cassava' as produced by the Igbo subjects. The short schwa (or the short, almost back RP vowel with lips neutrally spreading) is replaced by /a/, the alternative in Nigerian English. For the aspiration of $\mathrm{p}^{\mathrm{h}}$, our subjects rather than observe the aspiration produced the flat voiceless bilabial plosive consonant. The important factor about a phoneme like / $\mathrm{p} /$ is the place of articulation. Among the phonemes tested in the words listed in the table above, the voiceless alveolar plosive consonant, $/ \mathrm{t} /$ is a familiar phoneme to our subjects. So, in the production of the sound by our subjects, there was an overwhelming conformity to the Standard version of the sound in Standard English.

\subsection{Sex as Determinant of Variation}

Sociolinguistically, especially in surveys of language attitude, gender differences have been explored in experimental settings, for instance, by Smith (1985:86), Preston (1989:76), Elyan, et al. (1978) and Giles and Marsh (1979) among others. In most of these researches, female RP speakers were rated higher on both masculine and feminine stereotypes. However, in this section, we intend to compare feminine articulation of phonemes with that of the men, in order to corroborate or refute earlier findings.

In our corpus, there are 75 females. From each ethnic group, we choose 25 females. Space will not permit us to present the individual articulations of the entire female experimental group. However, we resort to acoustic means to clearly view gender variations in ENE. The Pratt computer software wave forms displayed below are representative of a male and a female speech analysis respectively. Although, the first spectral slice is that of a northerner, while the second is that of a southerner, the two speakers are of different genders. The difference between the two is in the thickness of the male's voice and faintness of the female's. While a woman's voice is naturally faint and tiny, that of a male is sonorous or deep. In the subsequent sections in this study, we shall present the result of the acoustic analysis of the three major varieties of English in Nigeria. The first slice below is the Pratt analysis of a male voice. Although, the first voice was recorded in Sokoto, northern Nigeria to test the articulation of some phonemes as 
produced by Educated Nigerian users of English as a second language, the second is that of an Easterner (Igbo). In this context, they are Nigerians.

Our concern here is the fact that the first voice is that of a male while the second is that of a female.

dan_fodio_take_2

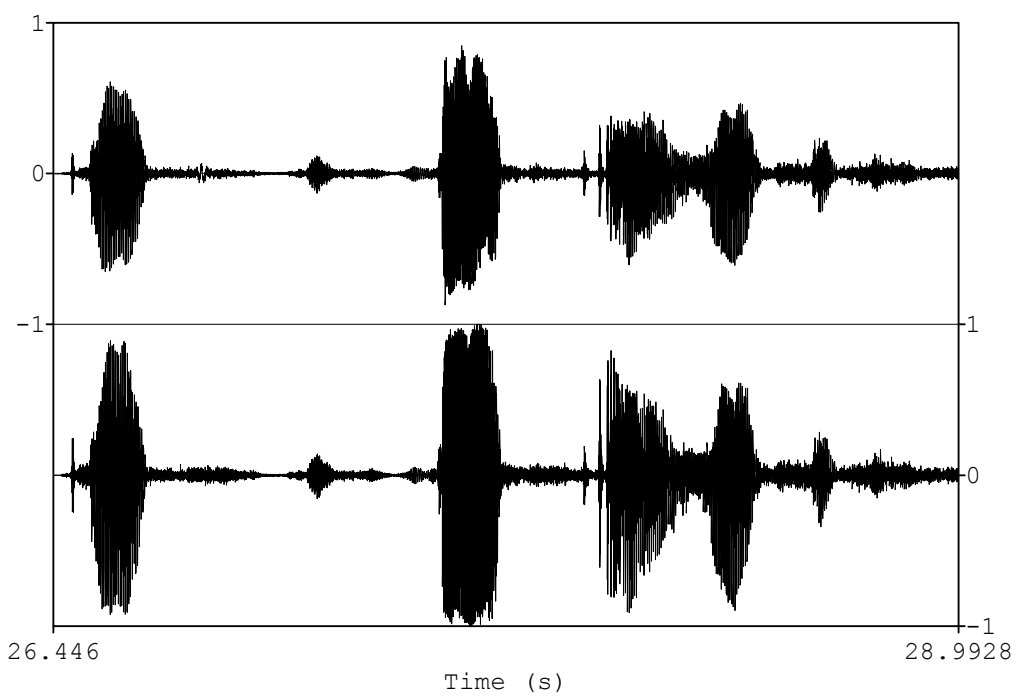

Figure 2a. Spectral Analysis of a Male Subject's Speech

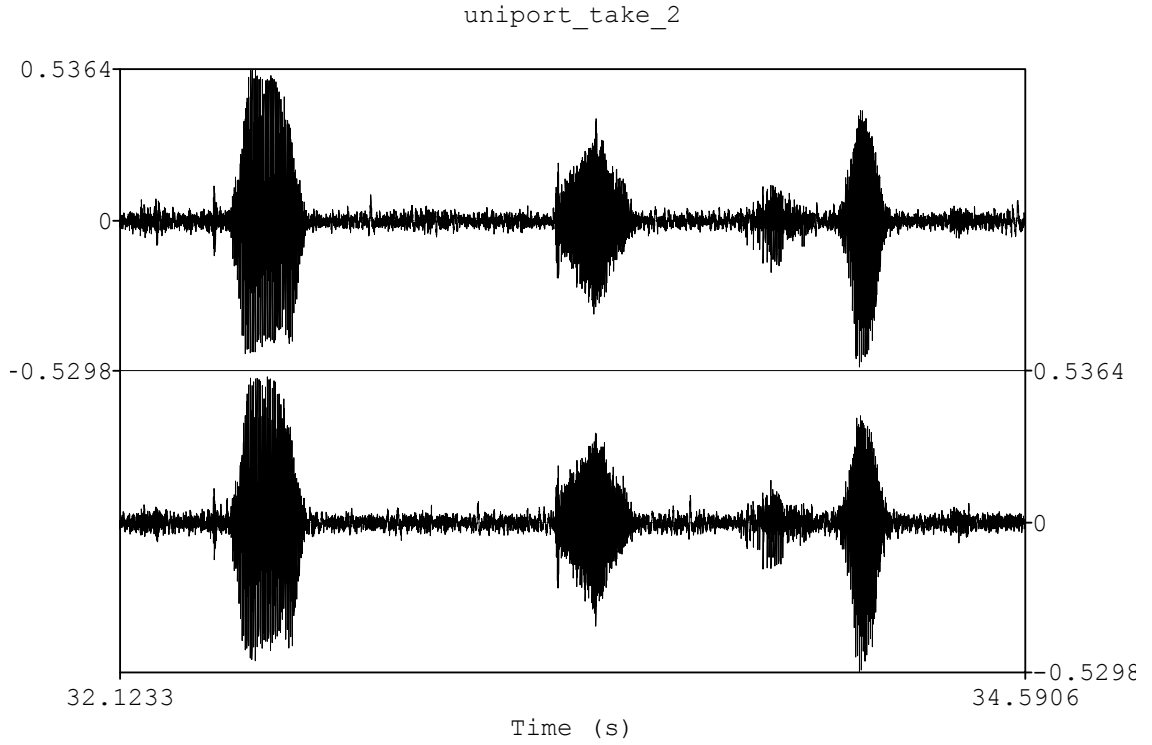

Figure 2b. Spectral Analysis of a Female Subject's Speech

The spectral slices above show the distinction between the articulatory forces in the speech of a man and a woman or preferably male or female. The analyses show that the voice of a male is thicker in quality if compared with that of a female. As much as this discovery is natural, we can not rely on it, thus we shall in the following section consider the individualness that is possible in speeches. In order to do this successfully, we shall persuade our subjects to repeatedly pronounce some phonemes.

\subsection{Individuality as Determinant of Variation}

In this section we present the result of a test carried out over and over again on some selected subjects. This repetition was necessary in order that we may test 'consistency' in individual articulation of phonemes. If the consistency or otherwise is ascertained, we would have a basis to argue that 'no speaker of a language, let alone two 
different speakers is consistent in the manner which he uses the language'. We were also not oblivious of personality traits that differentiate humans. Of course, individuality is a psychogenetic factor inseparable from related issues such as gender and age mentioned elsewhere in this study. The result from the foregoing effort is presented in table 18 below:

Table 5. Individual Test of RP Vowel Phonemes

\begin{tabular}{|c|c|c|c|c|c|c|c|c|}
\hline \multirow{2}{*}{$\begin{array}{l}\text { Ethnicity } \\
\text { HAUSA }\end{array}$} & \multirow{2}{*}{$\begin{array}{l}\begin{array}{l}\text { Speaker } \\
\text { number }\end{array} \\
1\end{array}$} & \multirow{2}{*}{$\begin{array}{l}\begin{array}{l}\text { Vowel } \\
\text { Phonemes }\end{array} \\
\partial\end{array}$} & \multicolumn{3}{|c|}{ Word Contexts } & \multirow{2}{*}{$\begin{array}{l}\text { Test } 1 \\
\mathrm{a}:\end{array}$} & \multirow{2}{*}{$\begin{array}{l}\text { Test } 2 \\
\mathrm{u}\end{array}$} & \multirow{2}{*}{$\begin{array}{l}\text { Test } 3 \\
\varepsilon\end{array}$} \\
\hline & & & Among & central & Development & & & \\
\hline & 2 & 3: & Bird & $\operatorname{sir}$ & Nerve & $\varepsilon$ & $\varepsilon$ & A \\
\hline & 3 & $\Lambda$ & Country & cup & Honour & $\Lambda$ & $\Lambda$ & $\Lambda$ \\
\hline & 4 & Э: & Caught & lord & Fort & J & J & כ \\
\hline & 5 & i: & Phoenix & read & Receive & I & $i$ & I \\
\hline \multirow[t]{5}{*}{ IGBO } & 1 & ə & Among & central & Development & A & $\mathrm{a}$ & $\varepsilon$ \\
\hline & 2 & 3: & Bird & $\operatorname{sir}$ & Nerve & $\varepsilon$ & $\varepsilon$ & A \\
\hline & 3 & $\Lambda$ & Country & cup & Honour & J & J & J \\
\hline & 4 & Э: & Caught & lord & Fort & $\mathrm{J}$ & $\mathrm{J}$ & $\mathrm{J}$ \\
\hline & 5 & i: & Phoenix & read & Receive & I & $i$ & I \\
\hline \multirow[t]{5}{*}{ YORUBA } & 1 & ə & Among & central & Development & A & $\mathrm{a}$ & $\varepsilon$ \\
\hline & 2 & 3: & Bird & $\operatorname{sir}$ & Nerve & $\varepsilon$ & $\mathrm{a}$ & A \\
\hline & 3 & $\Lambda$ & Country & cup & Honour & כ & כ & כ \\
\hline & 4 & ว: & Caught & lord & Fort & J & J & כ \\
\hline & 5 & i: & Phoenix & read & Receive & $\mathrm{i}$ & $\mathrm{i}$ & I \\
\hline
\end{tabular}

\section{Source: (Field work, 2011)}

Our findings in the analysis above go to show that variation in language, phonologically, is an inevitable occurrence. That is why we would conclude later on, that any claim of competence in a second language is sheer assumption. A speaker of a second language who may approximate the native standard in quality is one who acquired English as L1 and L2 in a native speaker environment. That is where the cognitive impulses come to play. Unlike other linguists, such as Chomsky, Labov was interested only in the ideal speaker - hearer and in an idealized language - as represented in our ideal speaker's competence. Variation in the words of Labov (1966) as quoted by Jibril (1982:31) is part of performance and thus outside the linguist's purview. As evident in table 19 above, we have shown in our experiment that no speaker was wholly consistent in his use of language, especially in a second language and that variation was explicable if studied in its proper social, stylistic and historical contexts.

The results of the tests above indicate that variation in phonemic realization is an individual as well as group characteristic. Another key variable that we have tested in this research is the Interference phenomenon. We observed that there are varying levels of competence among our subjects whom we considered as educated speakers of English. Among the broadcasters for instance, there are varieties or differences in their voice quality and approximation attempts of the R.P phonemes. The physiological reason for the differences in quality of voice has been explained elsewhere in Jibril (1982:49-50). We have managed to consider the most common forms of the phonemes as rendered by our ENE speakers in table 16, 18 and 19 above. Among the students, lecturers, and the professionals, we discovered discrepancies in the articulations of the ENE speakers.

Some of the following ascribed individual characteristics seem responsible for the varying competences in this study. The first sociolinguistic variable is age. Others that contribute to personality differences include sex, education and application to the learning of English as an additional language. In table 2 above the age of subjects who performed least in proficiency in comparison to others is that of the students. This corroborates Krashen's (1982:205-207) claim that "younger speakers are hit by the most important social pressures that come from the peer group, and linguistically they are more influenced by their friends than anybody else. Influence from the standard language is 
relatively weak". He claims that "younger broadcasters mature as they gain experience and spend longer years in practice. They improve in age and competence". Most of the broadcasters whose voice we recorded are not younger than 30 years. The older broadcasters, especially on the national television stations in Nigeria seem to approximate closest to the Standard English norm than the younger broadcasters. Age is thus a significant factor in linguistic competence.

Another important factor that we considered contributory to the varying competencies as mentioned earlier is the level of education. Education in relation to spoken English is viewed in terms of accompanying 'training' and motivation or exposure in the norms of the target language. Among all the respondents, in table 2 above, only the broadcasters according to our subjective competence rating have the 'enviable' variety of Nigerian English. The implication of the aforesaid so far is that second language acquisition and learning are two cognitive processes that are inseparable. While the acquisition process is "automatic", a learner of a second language who aspires to an enviable level of competence will have to undergo certain refinement, restructuring and consolidation to achieve that goal.

\section{Conclusion}

The variability theory that we have employed in this study is a merger of the entailments of Labov's (1966) variable rules elaborated by Preston (1989) as Ascribed and Acquired variables in Sociolinguistics. We have identified some ascribed individual characteristics in the sociolinguistic aspects of SLA to support the theory in the deciphering of sociolinguistic markers, and individual characteristics as well as cognitive impulses in the acquisition and learning of the standard norms of English.

We have come to a conclusion that variables such as education, training and exposure correlate markedly with the Nigerian English speakers' level of approximation to RP. This is contrary to Jibril's (1982:123) claim that level of education is not commensurate with level of proficiency in English. Articulations of Educated Nigerians are the Received Pronunciation (RP) equivalent of the South eastern England variety of English in Nigeria. Suffice it to say that ENE is supposed to be that educated variety of English in Nigeria with no regional accent. This level of articulation is then comparable to the RP in England based on Gimson's proposition in Cruttenden (2008:77)

We do agree with Jibril (1982:31) that 'no speaker was wholly consistent in his use of language and that variation was explicable if studied in its proper social, stylistic and historical contexts'. Apart from individuality, 'age' is another determinant of proficiency. Cognitive superiority according to Krashen (1982:205-207), explains why adult speakers of L2 perform better than the young. Obviously, in our study, the undergraduates are the least rated.

Our parting statement in this study is that culture as the total way of life of a people has a complete expression in the further tongues of the people. In summary, there exist different levels of competence demonstrated by speakers of English as a second language. The inconsistencies in individual and group performance are as a result of environmental, variational, interference, and individual physiological conditions. Thus, given the same education and exposure, humans possess varying cognitive abilities in language learning and acquisition.

\section{References}

Adegbija, Efurosibina. (2004). The Language situation in Nigeria and a Tentative Language Register. In Adegbija, E., Multilingualism: A Nigerian Case Study. Eritrea: Africa World Press Line.

Adetugbo, A. (1979). Appropriateness in Nigerian English. In E. Ubahakwe (Ed.), Varieties and Functions of English Language in Nigeria. Ibadan: African University Press.

Adetugbo, A. (1980). Nigerian English and Communicative Competence. In E. Ubahakwe (Ed.), Varieties and Functions of English in Nigeria (pp. 167-183). Ibadan: African Universities Press.

Akinjobi, Adenike. (2002). Nigerian English or Standard English Supra-segmentals: The question of what variety to teach. In Babatunde, S \& D. Adeyanju(Eds.), Language Meaning and Society, (pp. 30-50). Ilorin: Hatee Press.

Akmajian, A., Demers, R., Farmer, A., \& Harnish, R. (2001). Linguistics: An Introduction to Language and Communication ( $5^{\text {th }}$ Ed.). India: Prentice Hall.

Bamgbose, Ayo. (1971). The English language in Nigeria. In Spencer (ed.), The English Language in West Africa. London: Longman.

Banjo, A. (1971a). Towards a Definition of Standard Nigerian Spoken English. Annales de 'Universite d' Abidjan, 
24-28.

Banjo, Ayo. (1971). The English Language and the Nigerian environment. Journal of Nigeria English Studies Association, 4(1), 45-51.

Brann, C.M.B. (2006). Macro-Sociolinguistics in Africa: A Tentative Introduction. In Language in Education \& Society: An Anthology of Selected Writings of Brann, C.M.B.2005 .Maiduguri/ Jos: Fab Education Books

Brann, C.M.B. (2006). Mother Tongue, Other Tongue and Further Tongue. In Language in Education and Society: An Anthology of Selected Writings of Brann (1975-2005). Jos: Fab Education Books.

Brann, C.M.B. (2006). The De-lectable Field of Socio-Linguistic Variety Differentiation. In Language in Education \& Society: An Anthology of Selected Writings of Brann (1975-2005). Jos: Fab Education Books.

Crutenden, A. (1986). Intonation. NY: Cambridge University Press.

Cruttenden, A. (2008). Gimson's Pronunciation of English. London: Hodder Education.

Egbe, D. (1979). Spoken and Written English in Nigeria. In Ubahakwe, E (ed.), Varieties and Functions of English in Nigeria. Pp. 10-11.

Eka, David. (1985). A phonological study of Standard Nigerian English. Unpublished Ph.D thesis. Ahmadu Bello University, Zaria.

Elyan, O., Smith, P., Giles, H., \& Bourhis, R. (1978). RP accented female speech: the voice of perceived androgyny? In P. Trudgill (ed.), Sociolinguistic Patterns in British English(p122-131). London: Arnold.

Giles, H., \& Marsh, P. (1979). Perceived masculinity and accented speech. Language Sciences, 1, 301-315. http://dx.doi.org/10.1016/S0388-0001(79)80019-4

Jibril, M. (1982). Phonological Variations in Nigerian English. Unpublished Ph.D Dissertation, Lancaster University.

Josiah, Ubong. (2009). A Synchronic Analysis of Assimilatory Processes in Educated Spoken Nigerian English (ESNE). An Unpublished Ph.D Thesis. Department of English, University of Ilorin.

Jowitt, David. (1991). Nigerian English Usage: An Introduction. Ibadan: Longman.

Kachru, Brach. (1982, 1995). Models for non-native Englishes. In Kachru, B.B. (ed.), The other tongue, 31-57.

Krashen, Stephen. (1982). Accounting for child- Adult differences in second language rate and attainment. In S.D. Krashen, R.C. Scarcella, and M.A. Long (eds.), Child-Adult Differences in Second Language Acquisition, (pp 202-206). Rowley, Ma: Newbury House.

Kristiansen, Gitte. (2003). How to do things with allophones: Linguistic Stereotypes as Cognitive reference points in social cognition. In Dirven, René, Frank, Roslyn \& Pütz, Martin (eds.), Cognitive Models in Language and Thought: Ideology, Metaphors and Meanings(pp69-120). Berlin: The Hague.

Kujore, O. (1985). English Usage: Some Notable Nigerian Variations. Ibadan: Evans Brothers.

Labov, William. (1966). The Social Straification of English in New York City. Arlington, V.A.: Centre for Applied Linguistics.

Ogu, John.N. (1992). A Historical Survey of English and the Nigerian Situation. Lagos: Kraft Books Ltd.

Olajide, Billy \& Olaniyi, Oladimeji. (2013). Educated Nigerian English as core of a regional R.P. International of Humanities and Social Sciences, 3(14), 277-286.

Olaniyi, Oladimeji. (2011). Articulation as a means of identifying educated Nigerian English: a phono-sociolinguistic study. Unpublished Ph.D thesis. University of Ilorin. Department of English

Preston, D. (1989). Sociolinguistics and second language Acquisition. Blackwell: Oxford.

Sachdev, Itesh \& Richard, Y. Bourhis. (1990). Language and Social Identification. In Dominic Abrams and Michael A. Hoggs (Eds.), Social Identity Theory, Constructive and Critical Advances(pp216-217). Hemel Hempstead: Harvester - Wheatsheaf.

Smith, P. M. (1985). Language, the Sexes and Society. Oxford: Blackwell.

Ufomata, T. (1990). Thoughts on Spoken Nigerian English. Journal of Nigerian English Studies Association, 10(2), 13-20. 